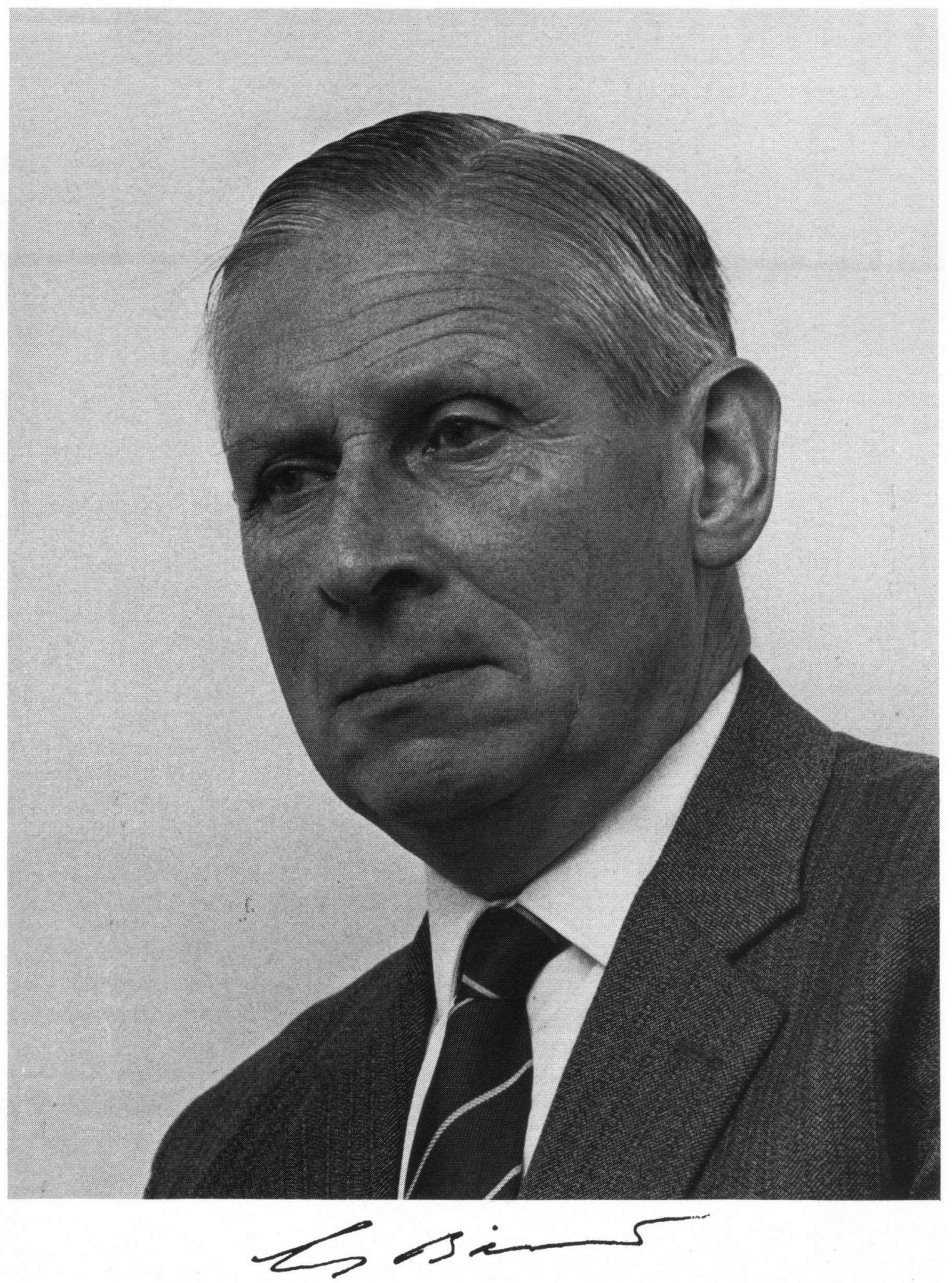

The selection of articles for this special number of Bijdragen tot de Dierkunde has been made on the responsibility of Drs. S. de Jager on the occasion of Prof. Dr. G. Barendrecht's seventieth birthday. 


\title{
PROF. DR. G. BARENDRECHT - VALEDICTORY NOTICE
}

\author{
by
}

\author{
A. VAN DER STELT \\ Zoological Laboratory, University of Amsterdam, The Netherlands
}

Prof. Dr. Gerard Barendrecht was born on the 9th of October 1906 in Hilversum. After his final examinations in Kampen in 1923 there came a year of private studies of Greek and Latin. These formative years resulted in a continuing interest in the classical writers which he still reads as a relaxation from more strenuous tasks. On the other hand, the polders in the neighbourhood of Kampen gave the inspiration to the writing of the "Glorie van ons polderland" ("Glory of our polderland").

In 1924 he entered the University of Amsterdam as a student in biology where he took his "doctoraal examen" (master's degree) in 1929. His doctor's degree dates from the 20th of January 1932. His thesis "Die Corpora pedunculata bei den Gattungen Bombus und Psithyrus" is an elegant synthesis of his former work in the Dutch Central Institute of Brain Research as an adjunct-assistent to Prof. Dr. C. U. Ariëns Kappers and his work with his promotor, the entomologist Prof. Dr. J. C. H. de Meijere.

The speedy progress of his studies would by later generations of biologists be taken as a scholarly achievement that may not be so easily surpassed in the present day. It may have had survival value for Dr. Barendrecht during the economic crisis and its effects on the university staff during the thirties. In fact he has been a "resident and officer" in our laboratory for more than forty years in all the various functions from assistent to Prof. de Meijere in 1932 up to Professor in General Zoology and Director of the Zoological Laboratory of the University of Amsterdam in 1970 . For many years a prominent member of the Dutch Entomological Society, his main field of interest in zoology has been the immense diversified world of insects. Those among us who have had the pleasure of attending his lectures on insect morphology and taxonomy, will still remember his clear and concise style with his critical appraisal of controversial points. Teaching is a profession, and it takes a professional to make of a course in insect morphology a lively and interesting story. This, indeed, he achieved. He insisted on pertinent differences in detail and kept a clear survey of essentials as a guide.

Even before his contacts with the Dutc.. Entomological Society, which he served in the functions of secretary and president for many years, his vocation was to what we call being a naturalist who is primarily interested in the life history of animals and the connected issue of environmental conservation. His interest in the preservation of the natural species and the problem-of the extermination of species is also long standing. Continuous contacts with morphologists interested in other topics have made him a general zoologist with an almost encyclopedic knowledge. The members of his scientific staff could rely on his good advice concerning problems of publication.

Prof. Barendrecht succeeded in amalgamating the diverse activities of our institute into two solid working groups. We are truly grateful for this, and for his help in promoting the many other affairs that belong to the tasks of a director of a university laboratory in times difficult for him personally as well as for the personnel entrusted to his care.

\section{ACKNOWLEDGEMENT}

For providing information on the early career of Prof. Dr. G. Barendrecht, I am grateful to his friend and colleague, Dr. G. Kruseman. 